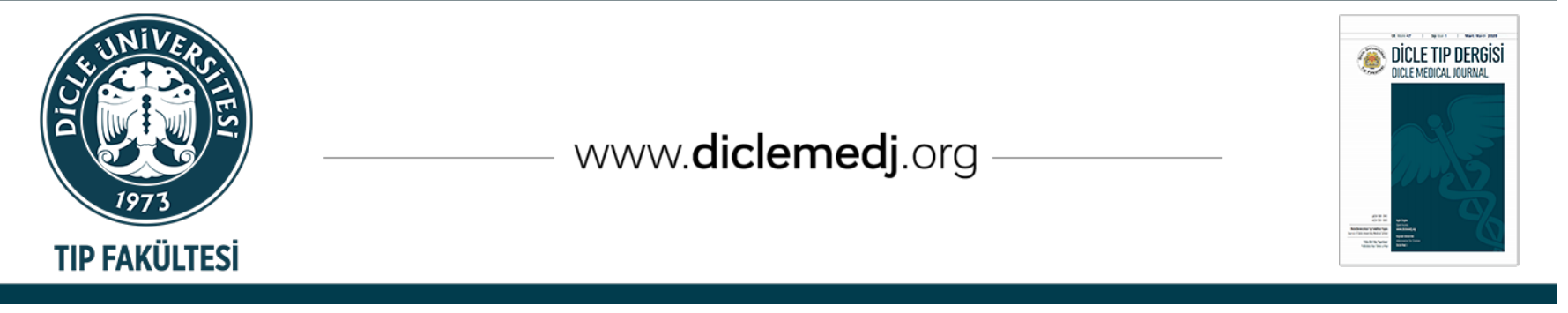

Original Article / Özgün Araştırma

\title{
Tuberculosis Knowledge Levels Of Secondary School Students
}

\author{
Şerif Kurtuluş ${ }^{1}{ }_{1}$, Remziye Can ${ }^{2}$ \\ 1 Harran University Faculty of Medicine, Department of Chest Diseases, Sanliurfa, Turkey \\ 2 Mustafa Kemal Atatürk Vocational and Technical Anatolian High School, Eskişehir, Turkey \\ Received: 30.06.2020; Revised: 25.08.2020; Accepted: 30.08.2020
}

\begin{abstract}
Objective: A reduction in tuberculosis (TB) cases is possible through knowledge and control of the risk factors. In this study, the aim was to evaluate the knowledge levels of secondary school students about TB.

Method: The study is a descriptive study conducted in 2018-2019. The sample of the study consisted of 116 students, who volunteered to participate in the study of 12th grade of the school. The data collection tool consists of 19 questions: Personal Information Form and TB Knowledge Level Questionnaire (TBKLQ). In TBDSF, every correct answer is one point. The score that can be obtained varies between 0-11.

Results: The mean age of was $17.17 \pm 0.37$ years. $1.7 \%$ of the study group had tuberculosis. The incidence of tuberculosis in their families was $2.6 \% .86 .2 \%$ of the participants knew the correct cause of the disease, $51.7 \%$ of them were aware of the symptoms and $64.7 \%$ of them understood the correct transmission path. $37.1 \%$ of the study group knew the duration of treatment correctly, $20.7 \%$ of them knew the infectious period correctly; $93.1 \%$ of the study group knew that TB was a notifiable disease and $76.7 \%$ knew that registration of TB should be undertaken at the Tuberculosis Dispensary. 50.9\% of the study group were aware that TB could be seen in the lungs and extrapulmonary organs, and $37.1 \%$ of them knew correctly when the TB vaccine should be administered. The mean TB knowledge score of the study group was $5.85 \pm 2.11$. $59.5 \%$ of the participants reported that they had received training on TB. A significant difference was found between the TB knowledge scores of those who previously received TB education with those who did not.
\end{abstract}

Conclusion: The knowledge level of individuals with high school education about TB is at a medium level. One out of every two participants received training on TB. In order to increase the effectiveness of the fight against tuberculosis, to prevent the spread of the disease and to reach the goals of the end tuberculosis strategy, the lack of information should be overcome.

Keywords: Awareness, Education, Student, Tuberculosis

DOI: 10.5798/dicletip.799965

Correspondence / Yazışma Adresi: SSerif Kurtuluş, Harran University Faculty of Medicine, Department of Chest Diseases, Şanliurfa, Turkey, e-mail: drkurtulus1@gmail.com 


\section{Ortaöğretim Düzeyindeki Öğrencilerin Tüberküloz Bilgi Düzeyleri}

Öz

Amaç: Tüberküloz (TB) vakalarında azalma, risk faktörlerinin bilinmesi ve kontrolü ile mümkündür. Bu çalışmada ortaöğretim öğrencilerinin TB'ye ilişkin bilgi düzeylerinin değerlendirilmesi amaçlanmıştır.

Yöntemler: Çalışma 2018-2019 yılında yapılmış bir tanımlayıcı çalışmadır. Çalışmanın örneklemini 12. sınıf öğrencilerinden çalışmaya katılmaya gönüllü 116 kişi oluşturmuştur. Veri toplama aracı Kişisel Bilgi Formu ve Tüberküloz Bilgi Düzeyi Soru Formu (TBDSF) olmak üzere 19 sorudan oluşmuştur. TBDSF' de her doğru cevap bir puandır. Alınabilecek puan 0-11 arasında değişmektedir.

Bulgular: Çalışma grubunun yaş ortalaması $17.17 \pm 0.37$ 'dir. Çalışma grubunun $\% 1,7$ 'si, tüberküloz geçirmiştir. Katılımcıların \%86,2'si hastalık etkenini, \%51,7'si belirtileri, \%64,7 bulaşma yolunu doğru bilmiştir. Çalışma grubunun $\% 37,1^{\prime} i$, tedavi süresini doğru biliyor iken, bulaştırıcllık süresini \%20,7'si doğru bilmiştir. Çalışma grubunun \%50,9'u TB'nin akciğer ve akciğer dışı organlarda görülebildiğini, \%37,1'i TB aşısının zamanını doğru bilmiștir. Çalışma grubunun \%93,1'i TB'nin bildirimi zorunlu bir hastalık olduğunu, \%76,7'si TB'ye ilişkin kayıtları tutan kuruluşun Verem Savaș Dispanseri olduğunu bilmiştir. Çalışma grubunun TB bilgi puan ortalaması $5.85 \pm 2.11$ 'dir. Katılımcıların \%59,5'u TB ile ilgili eğitim aldığını bildirmiștir. Önceden TB konusunda eğitim alanlar ile almayanların, TB bilgi puanları arasında anlamlı fark saptanmıștır.

Sonuç: Lise eğitimi alan bireylerin TB'ye ilişin bilgi düzeyinin orta seviyededir. Her iki katılımcıdan birinin TB hakkında eğitim almıștır. Tüberkülozla mücadelenin etkinliğini artırmak, hastalığın yayılmasını önlemek ve verem sonu stratejisinin hedeflerine ulaşmak için bilgi eksikliğinin giderilmesi gerekmektedir.

Anahtar kelimeler: Eğitim, Farkındalık, Öğrenci, Tüberküloz.

\section{INTRODUCTION}

In recent years, despite increasing efforts in the struggle to end tuberculosis (TB), the main gaps - resource-constrained environments in particular and environments with a high disease burden - render these efforts largely inadequate. 1.6 million people lost their lives in 2017 to TB, which continues to be one of the top 10 causes of deaths in the World 1,2 . 95\% of deaths occur in low and middle-income countries. In Turkey, the total number of patients diagnosed with TB in 2017 was 12,0463. According to the World Health Organization Global Tuberculosis Report published in 2016, it will look to contribute to the 'End of TB' strategies and to raise awareness in society of the importance of early diagnosis of TB. Studies in the literature have reported a positive relationship between TB information, care-seeking and treatment adherence ${ }^{1-3}$. In two different studies conducted in sub-Saharan countries, $66.3 \%$ to $99.7 \%$ were reported to have misconceptions about the etiology of TB,
$27.6 \%-90 \%$ likewise misunderstood the symptoms of TB, $0.1 \%-48.6 \%$ were mistaken with respect to its infectiousness, while $33.4 \%$ to $92.9 \%$ were incorrect as to methods of prevention ${ }^{4,5}$. In another study, healthy lifestyle behaviors are determinants of health has an important place. It can be said that infectious diseases such as tuberculosis will also be acquired by the right health behavior at an early age will prevent contamination. The aim of this study is to evaluate the level of knowledge of secondary school students about TB.

\section{METHOD}

The study is a descriptive study conducted in 2018-2019. The sample of the study consisted of 116 students, who volunteered to participate in the study of 12th grade of the Eskişehir Mustafa Kemal Atatürk Vocational and Technical Anatolian High School in the 20182019 academic year. Students were asked to complete a structured questionnaire. The first section of the questionnaire prompted 
demographic information (age, gender, family professions). In the second section, informative questions related to TB, control, and prevention methods. Mean of the data collection tool was developed in parallel with the drafting of the study. The Personal Information Form (8 Questions) and Tuberculosis Knowledge Level Questionnaire (TBKLQ) (11 questions) consisted of 19 questions, totally. The TBKLQ included the following questions:

What is the causative agent of tuberculosis?

What is one of the symptom of tuberculosis?

What is a definitive method of diagnosis?

What is the route of transmission of tuberculosis?

How long is the treatment period?

For how long is the patient infectious following treatment?

Which methods confer protection from TB?

Is tuberculosis a compulsory notification disease?

Which organ(s) does tuberculosis affect?

When do you think the tuberculosis vaccine should first be given?

Which institution is responsible for the records / follow-up of tuberculosis patients?

In the questionnaire, a score of 1 point is awarded for each correct answer. A possible score of between one and eleven can be obtained from the questionnaire.

Ethics: Ethical approval for the study was obtained from the Harran University, Medical Faculty, Department of Drug and Non-Medical Device Research Ethics Committee, number $18 / 12 / 35$. The participants were informed about the study and written and verbal consent was obtained in accordance with the principles of the Helsinki Declaration.

\section{Data Analysis}

For data analysis, the SPSS 21.0 statistical package program (SPSS Inc., Chicago, Illinois, USA) was used. The Kolmogorov-Smirnov test was used to determine whether the distribution of continuous variables was appropriate for the normal distribution. Variables were shown as mean \pm standard deviation. $p<0.05$ was accepted as statistically significant.

\section{RESULTS}

The mean age of the study group was $17.17 \pm 0.37$ years. $65.5 \%$ of our study group consisted of male students, and $34.5 \%$ were female. It was found that there was a difference between TB knowledge levels according to gender $(\mathrm{p}<0.05) .67 .2 \%$ of the mothers of the study group had both a primary and secondary education, and $54.2 \%$ of their fathers had both a high school and university-level education. $63.8 \%$ of the study group reported that their families had a moderate income.

It was found that $1.7 \%$ of the students in the study group had tuberculosis and $2.6 \%$ had a history of tuberculosis in their families. 59.5\% of the study group had previously obtained information about TB. It was found that TBKLQ scores of those who had information about TB before were significantly higher than those who did not. (Table 1). Of the students in the study group, $86.2 \%$ were correct with respect to the causative agent, $51.7 \%$ in relation to the symptoms, and $64.7 \%$ with regard to the transmission path.

In the study group, $57.8 \%$ of the students knew that detecting bacillus in the sputum was a definitive diagnostic method, $37.1 \%$ knew the correct treatment period, and $20.7 \%$ knew the correct infectious period. $93.1 \%$ of the students in the study group knew that TB was a notifiable disease. $56.1 \%$ of the study group knew that TB could be seen in both the lungs and extrapulmonary organs, while $37.1 \%$ knew the time for administration of the TB vaccine correctly. The number of people, who knew that the organization holding TB records was the Tuberculosis Dispensary, was 76.7\% (Table 2). Although not stated in the table, the mean TB knowledge score of the study group was $5.85 \pm 2.11$. 
Table I: Distribution of Working Group Participants according to various Sociodemographic Characteristics and TB Knowledge Level

\begin{tabular}{|c|c|c|c|}
\hline Gender & $\mathbf{N}$ & $\%$ & Test Value*/p \\
\hline Female & 40 & 34.5 & \multirow[b]{2}{*}{$1.648 / 0.09$} \\
\hline Male & 76 & 65.5 & \\
\hline \multicolumn{3}{|l|}{ Mother's Education } & \multirow{4}{*}{$0.143 / 0.931$} \\
\hline Illiterate & 1 & 0.9 & \\
\hline Elementary School & 78 & 67.2 & \\
\hline High School and Above & 37 & 31.9 & \\
\hline \multicolumn{3}{|l|}{ Father's Education } & \multirow{4}{*}{$1.999 / 0.157$} \\
\hline Iliterate & 0 & 0 & \\
\hline Elementary School & 51 & 43.9 & \\
\hline High School and Above & 64 & 54.2 & \\
\hline \multicolumn{3}{|l|}{ Family Income Level } & \multirow{4}{*}{$0.417 / 0.842$} \\
\hline Good & 39 & 33.6 & \\
\hline Moderate & 74 & 63.8 & \\
\hline Low & 3 & 2.6 & \\
\hline \multicolumn{3}{|l|}{ TB Migration Status } & \multirow{3}{*}{$0.248 / 0.804$} \\
\hline Present & 2 & 1.7 & \\
\hline Absent & 114 & 98.3 & \\
\hline \multicolumn{3}{|c|}{ TB Migration Status in Family } & \multirow{3}{*}{$0.433 / 0.693$} \\
\hline Present & 3 & 2.6 & \\
\hline Absent & 113 & 97.4 & \\
\hline \multicolumn{3}{|c|}{ Previous information about TB status } & \multirow{3}{*}{$3.291 / 0.001$} \\
\hline Present & 69 & 59.5 & \\
\hline Absent & 47 & 40.5 & \\
\hline
\end{tabular}

*The Mann-Whitney U test was used in paired groups and the Kruskal Vallis test was applied for more than two groups.
Table II: The Relationship between TBKLQ ** Distribution and Knowledge Level of TB in Working Group Partcipants

\begin{tabular}{|c|c|c|c|}
\hline & n & $\%$ & $\begin{array}{l}\text { Test } \\
\text { Value***/p }\end{array}$ \\
\hline \multicolumn{3}{|l|}{ Knowledge of transmission path of TB } & \multirow{4}{*}{$36.056 / 0.000$} \\
\hline No idea & 14 & 12.1 & \\
\hline $\begin{array}{ll}\text { Correct knowledge } & \text { (Mycobectrium } \\
\text { Tuberculosis) } & \end{array}$ & 100 & 86.2 & \\
\hline Incorrect knowledge & 2 & 1.8 & \\
\hline \multicolumn{3}{|l|}{ Knowledge of TB Symptoms } & \multirow{5}{*}{$7.971 / 0.019$} \\
\hline No idea & 17 & 14.7 & \\
\hline Diarrhea / Fever & 21 & 18.1 & \\
\hline Rash / Fever & 18 & 15.5 & \\
\hline Dry Cough/ Bloody Cough / Fever & 60 & 51.7 & \\
\hline \multicolumn{3}{|l|}{ Knowledge of TB Transmission Path } & \multirow{4}{*}{$2.336 / 0.126$} \\
\hline Via Blood & 15 & 12.9 & \\
\hline Via Droplet & 26 & 22.4 & \\
\hline Via Digestion & 75 & 64.7 & \\
\hline \multicolumn{3}{|l|}{ Knowledge of Definitive Diagnosis of TB } & \multirow{4}{*}{$28.262 / 0.000$} \\
\hline No idea & 30 & 25.4 & \\
\hline Detection of Bacillus in the Sputum & 67 & 57.8 & \\
\hline Blood test & 19 & 16.4 & \\
\hline & & & \\
\hline
\end{tabular}


Table 2 continued

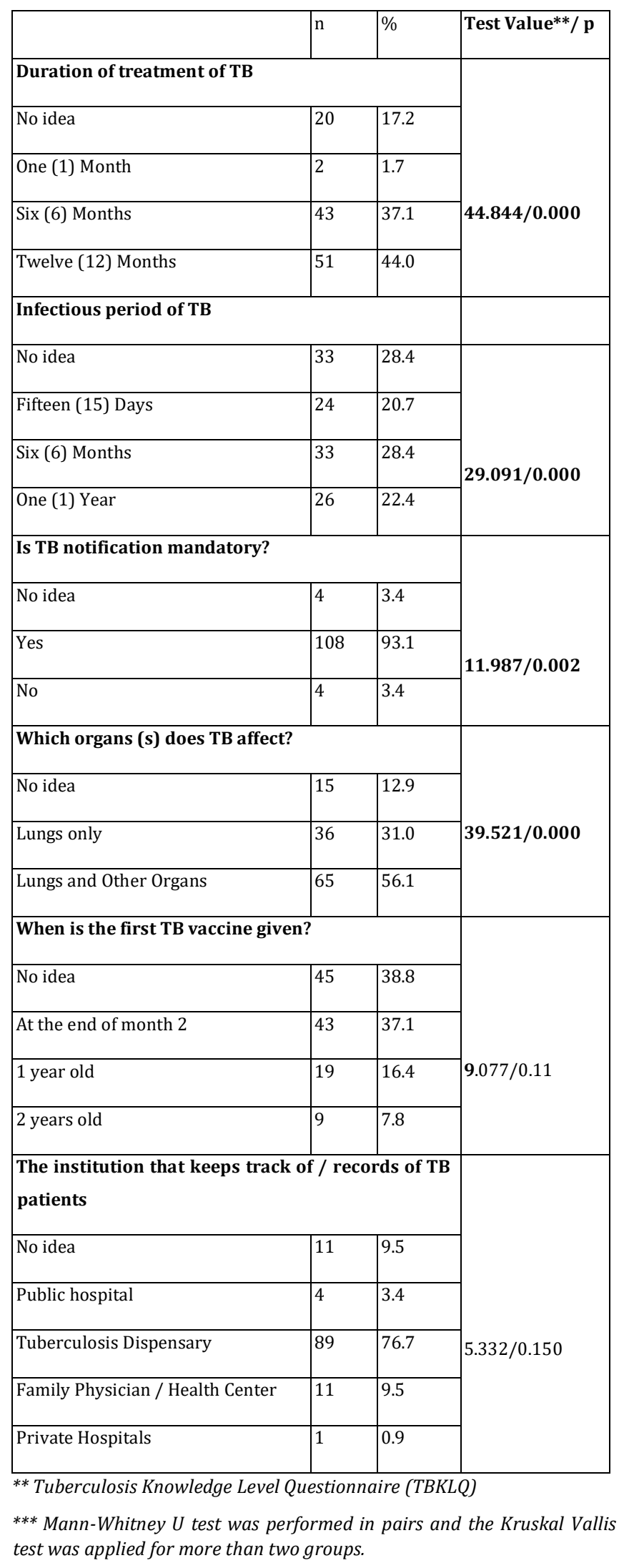

\section{DISCUSSION}

In 2017, 1.6 million people lost their lives due to $\mathrm{TB}$, which continues to be one of the top 10 causes of deaths in the world. It is known that $95 \%$ of deaths are in low and middle income countries ${ }^{3}$. This information supports the fact that $\mathrm{TB}$ is one of the most important and preventable diseases of developed and developing countries. In society, the way to gain knowledge or awareness of diseases is to either witness someone who had the disease or to have the disease yourself. However, this is not a desirable situation because of the consequences and the burden of the disease. In our study, the mean TB information score was $5.85 \pm 2.11$, and there was a statistically significant difference between TBKLQ scores of those who had information about TB before were significantly higher than those who did not. This result emphasizes the importance of obtaining information about the disease beforehand.

Knowing a disease-specific factor is one of the conditions for raising awareness about that disease $^{6}$. In our study, $86.2 \%$ of the participants were found to know the causative agent of TB correctly. The frequency of those who knew the correct agent of the disease was significant difference (Table 2). In another study, this rate was reported to be $37.7 \%{ }^{7}$. In a cross-sectional study conducted with 1200 medical students in China, the frequency of those who knew that the mycobacterium avium complex was the most common factor in the etiology of TB was $6.4 \% 8$. The reason our results differ from studies in the literature may be due to the fact that our study group consisted of students, who were in high school and who were senior students. Although there are many studies investigating the level of knowledge in different sample groups in the literature, there are only two studies that question the causative agent of tuberculosis.

The most common symptom of pulmonary TB is a persistent cough, and usually but not always, mucous, which is sometimes bloody 
(hemoptysis) $^{9}$. In our study, $51.7 \%$ of the participants, ie one in two, reported that cough was a symptom of the disease. It was determined that the frequency of those who knew the TB symptoms correctly significant difference (Table 2). Demir et al (2016) were found this rate $46.8 \%{ }^{10}$. Adane et al. (2017) reported the prevalence of cough as one of the most common symptoms of TB - 79.1\%. The reason for this result, which is similar to that in the literature, may be due to scenes of bloody coughing in films about tuberculosis.

The route of transmission of TB is the airway ${ }^{11}$. In our study, it was found that $22.4 \%$ of the participants knew the correct mode of transmission of TB. In a study of Demir et al.,(2016) it was found that $84.2 \%$ of the students of medical faculties and $42.8 \%$ of noneducated students knew the transmission path. In a study conducted by Aylk et al (2013), of 44 patients with and without tuberculosis, $43.2 \%$ of TB cases and $50 \%$ of non-TB cases correctly identified the mode of transmission ${ }^{12}$.

A definitive diagnosis of pulmonary tuberculosis is made by showing the presence of tuberculosis bacilli in the sputum and / or by growing the bacilli in cultures, if possible. Bronchial lavage is applied to those who cannot produce sputum or an examination conducted of the gastric juices in those who are fasting ${ }^{13}$. In our study, it was found that one in every two high school students knew the definitive method of diagnosis (57.8\%). It was observed that the frequency of those who knew that they were diagnosed with Bacillus Detection in Sputum was significantly higher (Table 2). In a study conducted of medical faculty students, the figure was $70.9 \%$ for those undertaking related studies, and $24.3 \%$ for those who were not. In the literature, this rate varies between 75.3$83.6 \%$ in different studies conducted with physicians ${ }^{14,15}$.

The standard treatment period for tuberculosis is 6 (six) months ${ }^{16}$. In our study, participant of
$37.1 \%$ stated that the duration of treatment was six months and participant of $44 \%$ stated that it was 12 (twelve) months. It was observed that the frequency of those who knew that the treatment period was 12 months made a significant difference compared to the other groups (Table 2). In a study by Demir et al. (2016) the rate of those who knew the correct treatment period was $58 \%$ with respect to those who were untrained, and $83.7 \%$ in relation to those who had training ${ }^{10}$. In a study by Kara et al. (2015) the rate was $86.4 \% 14$. Our results were found to be lower than those of other studies in the literature. The reason why the result we have obtained is different from the literature, may be due to the low number of patients in the family members. One of the most common aspects encountered in tuberculosis is the period of infectiousness of the disease. In our study, $20.7 \%$ of the participants knew the correct infectious period. The majority of the study group reported that infectiousness ranged from six months to twelve months. It was observed that those who knew that the contamination period was fifteen days in TB made a significant difference (Table 2). In the study of $38.6 \%$ of TB cases and $23.3 \%$ of non-TB cases stated that TB was an infectious disease ${ }^{12}$. The results obtained in the literature and in our study may be an indicator of the problem of social isolation experienced by the people who have the disease.

The notification of tuberculosis disease is important in terms of the control of infectious diseases, decreasing the number of contacts and increasing treatment success. $93.1 \%$ of the study group stated that tuberculosis is a notifiable disease. It was observed that the frequency of those who knew that reporting TB was mandatory significant a difference (Table 2). In a study conducted by Enginyurt et al. (2016), in a research hospital with health workers, it was reported that $82.5 \%$ knew that tuberculosis was a notifiable disease ${ }^{17}$. This 
result supports the fact that people have sufficient information to provide necessary control.

Tuberculosis may be involved in many organs, especially the lungs ${ }^{9,11}$. In our study, one out of two participants (56.1\%) stated that tuberculosis can be seen in both of the lungs and extrapulmonary organs. The frequency of those who knew that TB showed involvement in the lungs and other organs was significantly higher (Table 2 ). In a study by Kara et al. (2015) of pediatric residents, the figure was 96.1\% ${ }^{14}$. In the study of Aylk et al. (2013), 72.9\% stated that TB showed pulmonary involvement ${ }^{12}$.

Vaccination, which is the most important method of prevention, can prevent the occurrence of infectious diseases, as well as reduce the burden of disease. It is recommended that the BCG vaccine be given to infants 2 months after birth ${ }^{3} .37 .1 \%$ of the respondents gave the correct answer to the question about when the first BCG vaccine for TB should be given. There was no difference between the groups in the study of Demir et al. (2016) only $59.6 \%$ of the medical faculty students, who had studied the subject, knew the correct timing for the vaccination ${ }^{10}$. In the study of Aylk et al. (2013) $13.6 \%$ of $\mathrm{TB}$ cases and $16.6 \%$ of non-TB cases correctly identified the timing of the BCG vaccination ${ }^{12}$.

Although tuberculosis patients first learn of their disease in a hospital, tuberculosis dispensaries are the place where the patient is monitored and direct supervised treatment is carried out effectively ${ }^{11}$. In our study, $76.7 \%$ of participants correctly recognized the institution that kept / monitored the records of TB patients. There was no difference between the groups. The studies in the literature were mostly carried out on the symptoms and methods of prevention of tuberculosis and no questions were posed in relation to tuberculosis dispensaries. This has limited the discussion of our study. Our study shows that seven out of ten people have knowledge about TB dispensaries. The high public awareness is important of TB dispensaries in terms of continuity of treatment and reduction of contamination.

\section{CONCLUSION}

The results of this study indicate that individuals in receipt of a high school education lack sufficient knowledge about the diagnosis, treatment and follow-up of TB. In order to increase the effectiveness of the fight against tuberculosis, prevent the spread of the disease and in order to achieve the objectives of the End of TB strategy, the lack of information evident in these groups in all areas of society should be addressed.

The study abstract "Evaluation of Tuberculosis Knowledge Levels of Secondary School Students" 29. National Tuberculosis and Chest Diseases Congress, Turkey's National Tuberculosis Association Federation will be held between 17-19 January 2019. Porto Bello Hotel - Antalya - Turkey.

Ethics Committee Approval: Ethical approval for the study was obtained from the Harran University, Medical Faculty, Department of Drug and NonMedical Device Research Ethics Committee, number $18 / 12 / 35$. The participants were informed about the study and written and verbal consent was obtained in accordance with the principles of the Helsinki Declaration.

Declaration of Conflicting Interests: The authors declare that they have no conflict of interest.

Financial Disclosure: No financial support was received.

\section{REFERENCES}

1. Storla DG, Yimer S, Bjune GA. A systematic review of delay in the diagnosis and treatment of tuberculosis. BMC Public Health. 2008; 8: 1.

2. Cramm JM, FinkenfluÈgel HJ, Møller V, et al. TB treatment initiation and adherence in a South African community influenced more by perceptions than by knowledge of tuberculosis. BMC public health. 2010; 10: 1.

3. Tuberculosis Diagnosis and Treatment Guide. (2019). Ministry of Health (Ed: Kara F.) https://hsgm.saglik.gov.tr/depo/birimler/tuberkuloz_d b/haberler/Tuberkuloz_Tani_Ve_Tedavi_Rehberi_/Tube rkuloz_Tani_ve_Tedavi_Rehberi_08.07.2019_Yuksek_KB. pdf

4. Esmael A, Ali I, Agonafir M,et al. Assessment of patients' knowledge, attitude, and practice regarding pulmonary tuberculosis in eastern Amhara regional state, Ethiopia: cross-sectional study. Am. J. Trop. Med. Hyg. 2013; 88: 785-8. 
5. Amo-Adjei J, Kumi-Kyereme A. Myths and misconceptions about tuberculosis transmission in Ghana. BMC Int Health Hum Rights. 2013; 13: 1.

6. Gele AA, Bjune G, Abebe F. Pastoralism and delay in diagnosis of TB in Ethiopia. BMC Public Health 2009; 9: 5.

7. Adane, K., Spigt, M., Johanna, et al. Tuberculosis knowledge, attitudes, and practices among northern Ethiopian prisoners: Implications for TB control efforts. PloS one, 2017; 12, e0174692.

8. Yangjiang O., Zhenzhou L., Jinsong M., et al. Knowledge and determinants regarding tuberculosis among medical students in Hunan, China: a cross-sectional study . BMC Public Health. 2018; 18: 730.

9. Babalık A. (2019). Tuberculosis and Cough. Cough (Ed: Kalyoncu A.F., Özülgen K.) Turkish Thoracic Society Publication.Toraks Books Issue: 26.

10. Demir M., Aslan E., Taylan M., et al. The Knowledge Levels of Medical Faculty Students About Tuberculosis Disease. Dicle Med. J. 2016; 43: 265-70.

11. Ministry of Health Tuberculosis Diagnosis and Treatment Guidelines. (2011). Ankara https://www.toraks.org.tr/uploadFiles/301020141335 30-tuberkuloz_tani_ve_tedavi_rehberi.pdf
12. Ayık S., Karasu I., Çil E., et al. Knowledge of Patients About Tuberculosis Disease. İzmir Chest Disease Journal. 2013; 27: 2 .

13. Ateş G, Akyıldız L, Yıldız T. The usage of sputum smear specimens in the diagnosis of 117 pulmonary tuberculosis cases. Dicle Med J. 2007; 34: 33-7.

14. Kara, A., Doğar, Ö., Kanık Yüksek. S. Et al. Awareness and knowledge of pediatric residents about tuberculosis. Izmir Behçet Uz Journal of Pediatrics. 2015; 48-53.

15. Deveci SE, Turgut T, Acik Y, et al. Knowledge, attitudes and behaviors of primary care physicians about pulmonary tuberculosis and treatment approaches. Tuberk Thorax. 2003; 51: 40-7.

16. Davies PD, Yew WW. Recent developments in the treatment of tuberculosis. Expert Opin Investig Drugs. 2003; 12: 1297- 312.

17. Enginyurt Ö., İşcanlı M.D., Kılıç M., et al. Evaluation of Clinical Medicine Journal of Family Practice 2016; 8. 